\title{
Yield and fruit quality of peach scion by using rootstocks propagated by air layering and seed
}

\author{
Luciano Picolotto ${ }^{1}$; José Carlos Fachinello2*; Valmor João Bianchi; Roberta Manica- \\ Berto $^{4}$; Mateus da Silveira Pasa ${ }^{4}$; Juliano Dutra Schmitz ${ }^{4}$ \\ ${ }_{2}^{1}$ Embrapa/CNPCT - Rod. BR 392, km 78 - 96050-500 - Pelotas, RS - Brasil. \\ ${ }^{2}$ UFPel/FAEM - Depto. de Fitotecnia, C.P. 354 - 96010-900 - Pelotas, RS - Brasil. \\ ${ }^{3}$ UFPel/IB - Depto. de Botânica, C.P. 354 - 96010-900 - Pelotas, RS - Brasil. \\ ${ }^{4}$ UFPel/FAEM - Programa de Pós-Graduação em Agronomia. \\ *Corresponding author <jfachi@ufpel.tche.br>
}

\begin{abstract}
In rootstock propagation, several methods can be used; however few practices are adopted due to the lack of information about the behavior of stionic combinations at field. The work aimed to compare the propagation method by air layering with the traditional propagation system by seeds using the scion peach [Prunus persica (L.) Batsch] cultivar Granada. The following variables were measured: yield, fruit weight and size, skin color, flesh firmness, total soluble solids content (TSS) and titatrable acidity (TA), TSS/TA ratio, total phenols, trunk diameter and pruning mass. Yield, total phenols and titatrable acidity were higher when using the air layering propagation. There was no difference between propagation methods regarding color and diameter of fruit, flesh firmness and total soluble solid and TSS/TA ratio. Depending on propagation method, the fruit weight did not differ, nevertheless using the seed propagated Capdeboscq rootstock fruit weight was heavier. Plant behavior in each propagation method depended on the rootstock used. Scion cultivar (cv.) Granada on air layering rootstock-derived keeps similar or superior yield and same attributes of fruit quality, better than using rootstocks derived from seeds.
\end{abstract}

Key words: Prunus persica (L.) Batsch, plant propagation, rootstocks, yield and fruit quality

\section{Produtividade e qualidade de fruto de pessegueiro utilizando porta-enxertos propagados por alporquia aérea e semente}

\begin{abstract}
RESUMO: Na propagação de porta-enxertos vários métodos podem ser usados, no entanto alguns são pouco utilizados devido à falta de informação sobre o comportamento das plantas a campo. Avaliou-se o método de propagação de porta-enxertos por alporquia comparado ao sistema tradicional de propagação por meio de sementes no pêssego [Prunus persica (L.) Batsch] cv. copa Granada. Avaliaram-se as seguintes variáveis: produtividade, peso de fruto, coloração da epiderme, firmeza de polpa, teor de sólidos solúveis totais (SST) e acidez titulável (AT), relação SST/AT, tamanho de fruto, fenóis totais, diâmetro de tronco, e peso de poda. A produtividade, fenóis totais e acidez titulável foram maiores quando utilizado o método de propagação por alporquia. Não houve diferenças entre os métodos de propagação para coloração e diâmetro de fruto, firmeza de polpa e sólidos solúveis totais e relação sólidos solúveis totais e acidez titulável. Dependendo do médoto de propagação, o peso do fruto não se diferencia entre os porta-enxertos. Para o porta-enxerto Capdeboscq os frutos maiores foram obtidos com a propagação com sementes. O comportamento dentro de cada método de propagação está relacionado com o tipo de porta-enxerto utilizado. A cultivar (cv.) copa Granada, sobre portaenxerto obtido por alporquia aérea, mantém a produtividade igual ou superior e com os mesmos atributos de qualidade de fruto do que quando utilizado o método de propagação de porta-enxertos por semente.

Palavras-chave: Prunus, propagação vegetativa, porta-enxerto, produção e qualidade das frutas
\end{abstract}

\section{Introduction}

The basic propagation of stone trees is carried out by grafting on rootstock derived from seeds, which provides plants with pivotant roots, whereas vegetative propagation induces fasciculate and superficial roots (Fachinello at al., 1996). The root system is essential for many plant adaptive functions including water and nutrient uptake, soil fixation and stabilization of biotic interactions in the rhizosphere. Changes in the root architecture of the rootstock might severely affect plant capacity to water and nutrient uptake (López-Bucio et al.,
2003). The importance of root architecture on plant yield derives from that the soil resources are uneven distributed or are subject to located exhaustion; so the spatial distribution of the roots becomes a significant measurement to determine the exploration capacity of these resources (Lynch, 1995).

Among plant propagation methods, air layering has been used in plant propagation, although there is no description on peach trees [Prunus persica (L.) Batsch] (Castro and Silveira, 2003). Air layering is a process of asexual multiplication where the originated plant is only detached from mother plant after its root formation 
(Fachinello et al., 2005). In spite of having many researches about adventitious rooting in rootstocks and scion cultivars of peach, there is no commercial orchard formed by air layering cited in Brazil especially due the lack of information about the plant behavior at field when using this kind of propagation (Pereira and Mayer, 2005). Giorgi et al. (2005) highlight the importance of a precise evaluation of rootstocks and scions as well as the identification of their best combinations, since peach rootstocks have some influence on the scion cultivar performance (Zarrouk et al., 2005).

The cultivar Okinawa is originated from Japan and it was taken to the United States in 1953 where it was selected as rootstock from seeds. Its chilling requirement is low and it is very exigent with the spring temperatures. The cultivar Aldrighi was extensively used in the fifties and beginning of the sixties of the last century by growers from the region of Pelotas as candied fruit. Afterwards, it was used as rootstock (Rocha et al., 2007) as having good affinity with most cultivar, inducing medium vigor and yield (Rossi et al., 2004).

The work aimed to compare the propagation method by air layering with the traditional propagation system by seeds using the scion cultivar Granada.

\section{Material and Methods}

The work was carried out at the Rio Grande do Sul State/Brazil, from 2006 to 2008. The geographic coordinates of the region where the experiment was set were $31^{\circ} 52^{\prime} \mathrm{S}, 52^{\circ} 21^{\prime} \mathrm{W}$, altitude of $13.24 \mathrm{~m}$. The orchard was implanted in 2003 with $5.0 \times 1.5 \mathrm{~m}$ spacing. The scion cultivar Granada grafted on the following peach roostocks (Prunus persica (L.) Batsch): Aldrighi, Capdeboscq and Okinawa were used. Two methods of propagation were used: by seed or air layering. Fruit skin color was obtained by using a Minolta 300 colorimeter. The color measurements were taking in tridimensional scale and expressed in luminosity (L). The coordinates $\mathrm{a}^{*}$ (green to red) and $\mathrm{b}^{*}$ (blue to yellow) indicate color directions, and color tonality was expressed as hue angle $\left(h^{0}=\tan ^{-1} b / a\right)$. Flesh firmness $(N)$ was taken by a manual penetrometer (FT327) with $8 \mathrm{~mm}$ tip in the equatorial region of the opposite sides of the fruit. Total soluble solid content (TSS) was determined by portable analog refratometer and expressed in ${ }^{\circ}$ Brix. Total titratable acidity - TA (\% of citric acid): $10 \mathrm{~mL}$ of fruit juice was diluted into $90 \mathrm{~mL}$ of distilled water with posterior titration with $0.1 \mathrm{M} \mathrm{NaOH}$. A digital pHmeter Mettler Toledo (model 320), with an electrode Mettler Toledo (Inlab 413) to $\mathrm{pH} 8.10$ (step-up point) was used. Results were expressed in \% of citric acid by the formula $=(\mathrm{V}$ $\mathrm{x} \mathrm{N} \times \mathrm{f} \times 100 \times 0.064) / \mathrm{P}$, where $\mathrm{V}=\mathrm{n}^{\mathrm{o}}$ of $\mathrm{ml}$ of the 0.1 $\mathrm{M} \mathrm{NaOH}$ solution spent in titration, $\mathrm{f}=$ factor of the $\mathrm{NaOH}, \mathrm{N}=0.1 \mathrm{M}, \mathrm{P}=\mathrm{n}^{\circ}$ of $\mathrm{g}$ or $\mathrm{mL}$ of the sample used on titration. Total phenol content represents the equivalence of $\mathrm{mg}$ of galic acid for $100 \mathrm{~g}^{-1}$ by a calibration curve (mg EGA $100 \mathrm{~g}^{-1}$ ) and was quantificated using the Folin-Ciocalteau method (Singleton and Rossi,
1965). For better result comprehension data of plant growth and vigor was included: (i) trunk diameter of the scion $\mathrm{cv} .(\mathrm{mm}), 10 \mathrm{~cm}$ above grafting point, and (ii) pruning mass $(\mathrm{g})$.

Seed rootstock propagation was done using the late cultivars under study, sowed in the field nursery. Later, inverted T-budding using active bud was done. In the process of the rootstock propagation by air layering an entire $1 \mathrm{~cm}$ large ring was removed from each branch until reaching the cambium region. Then, this area was treated with $2 \mathrm{~g} \mathrm{~L}^{-1}$ indolbutiric acid (IBA) solution and wrapped in soil and black plastic.

Trees were trained in an Epsilon system orientation which consisted in a cut in the trunk at $40 \mathrm{~cm}$ high from soil and posterior selection of perpendiculars branches to line planting. Fruit winter pruning and postharvest pruning were done. In the fruit thinning a fruit was kept every 8 to $10 \mathrm{~cm}$ in vigorous branches and 12 to $15 \mathrm{~cm}$ in lesser vigorous ones. In the experiment trees were not watered and planted in a soil classified as Typic Hapludult. Cultural practices were done according rules of the peach integrated production. Fruit samples were randomly picked from the four quadrants of the tree.

The experimental design utilized was three complete randomized blocks, using a 3 (rootstock) $\times 2$ (propagation method) factorial and three replications per block. For fruit analyses 13 fruits per replication were used, totaling 39 fruits. Data were submitted to the test of comparison of means (Duncan, $p<0.05$ ) and variance analyzes were performed by using Sanest statistic program (Zonta and Machado, 1995). Evaluations of yield, fruit mass, trunk diameter and fruit weight were measured with data from productive seasons of 2006 to 2008 and the remaining variables with data from 2006 and 2007.

\section{Results and Discussion}

Peach yield of the cultivar Granada was affected by rootstocks and propagation method. The highest yield was reached on the rootstocks propagated by air layering, regardless of rootstock cultivar. Aldrighi followed by Capdeboscq were among the more productive rootstocks. Regarding seed propagation, Capdeboscq achieved the highest yield. For both propagation methods the rootstock with lower yield was Okinawa (Figure 1). The yield of the cv. Granada found here was similar to the values found by Rossi et al. (2004) (0.1 to $8.6 \mathrm{t}$ $\mathrm{ha}^{-1}$ ). In general, the low yield of 'Granada' is verified in most producing regions and could be related to the lack of chilling in some years and frequent thermal fluctuations in winter what are inappropriate to development and dormancy breaking of the buds (Nava et al, 2009).

The variation on yield may occur due to the use of different rootstocks and also to characteristics probably linked to the root system formed in the air layering or seed propagations. The capacity of plants to compete for resources uptake is narrowly related to root architecture (Sorgona et al., 2007). For Webster (2004), it is pos-

Sci. Agric. (Piracicaba, Braz.), v.67, n.6, p.646-650, November/December 2010 
sible that small root systems are less efficient, as an example on water uptake. A hypothesis is that herein the superficial distribution of the root system formed in the air layering propagation has been favored by the higher fertility of the first soil horizons.

Fruit weight varied according propagation method and rootstock. The propagation method did not induce fruits with different weights, except trees grafted on 'Capdeboscq' where seed propagation generate heavier fruits than whether using air layering propagation. Among rootstocks weightier fruits were found in the scion when using 'Okinawa' and 'Aldrighi' as rootstock originated by air layering propagation, than from Capdeboscq. There was no variation in fruit weight on scion grafted on rootstocks propagated by seeds (Figure 1). Fruit weight varied from 88 to $115 \mathrm{~g}$ and was similar to data found by Rossi et al. (2004) for the same cultivar. Variation in fruit weight when using different rootstocks was also verified by Rocha et al. (2007) and Remorini et al. (2008). According to Loreti and Massai, (2002) fruit weight is influenced by rootstock vigor and, possibly, by root anatomy (Baldini, 1992). Therefore,
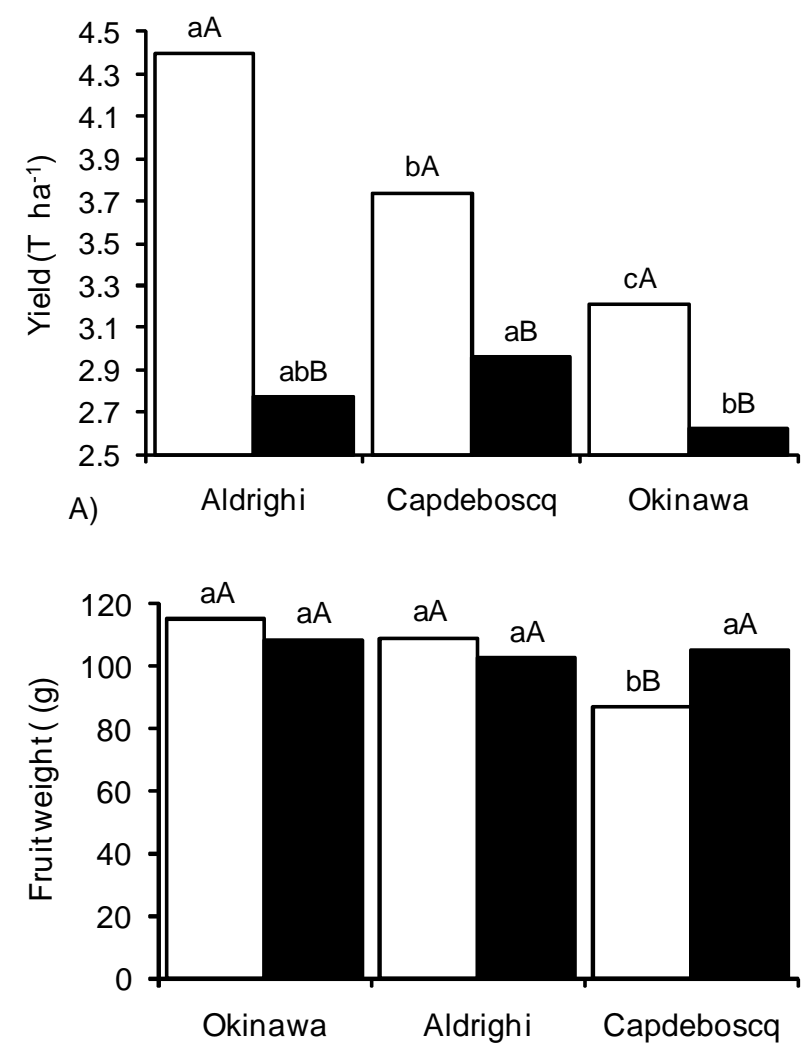

B)
口Air layering propagation $\mathbf{S}$ Seed propagation

Figure 1 - Yield and fruit weight of the peach cv. Granada grafted on different rootstocks and using two propagation methods. Means followed with the same letter, lowercase between rootstock and uppercase between propagation method, are not different (Duncan, $p<0.05$ ). fruit weight can be modified by the use of different propagation methods and rootstock type. Neither propagation method nor rootstock cultivar affected fruit diameter. The variation effects on fruit weight and the similarity of fruit diameter suggest that there was higher influence of the rootstock on the longitudinal fruit growth.

No effect of the propagation method on fruit skin color was observed, but so among the rootstock used. The use of rootstocks $\times$ Aldrighi $^{\circ}$ and $\times$ Capdeboscq allowed the formation of peaches redder than those obtained from trees on $\times$ Okinawa' (Table 1). Picolotto et al. (2009) also observed fruits less red on trees cv. Chimarrita grafted on Okinawa when compared with 'Aldrighi' and 'Capdeboscq'. Yellower color (B) in fruits was similar for all rootstocks. The lowest value of the angle $\mathrm{h}^{\circ}$ was observed on fruits taken from trees on 'Aldrighi'and 'Capdeboscq'. Anthocyanin accumulation causes reduction in values of $\mathrm{L}$ and $\mathrm{h}^{\circ}$ and reflects on the green-red changing (Amarante et al., 2007). Rootstock did not affect fruit luminosity. The variation of the intensity of red color on fruits is probably associated to the light amount that penetrates in the inner part of the canopy. The yield increase observed when using the rootstocks Capdeboscq and Aldrighi, probably was that these promoted a better opening of the branches what facilitated good light penetration to the inner parts of the tree when compared with Okinawa. Amarante et al. (2007) affirm the influence of quality and light amount on the red color of apple fruits cv. Fuji.

Regarding flesh firmness there was no difference between seed or air layering propagation, except fruits on trees raised on 'Aldrighi'. Fruits from the latter rootstock were firmer when the rootstock was propagated by seed. Using air layering propagation Capdeboscq promoted firmer fruits, differing from the other two rootstocks (Table 2); whereas rootstocks derived from seed did not differ in flesh firmness.

These firmness results when using seed propagation and different rootstocks are backed up with Rocha et al. (2007) and Giorge et al. (2005); however, they did not agree with the results found by Picolotto et al. (2009) and Remorini et al. (2008). Results in fruit flesh firm-

Table 1 - Epidermis color in the equatorial region, luminosity (L), direction of red or green (A), direction of yellow or blue (B) and color tonality $\left(\mathrm{h}^{\circ}\right)$ of the peach $\mathrm{cv}$. Granada grafted on different rootstocks.

\begin{tabular}{lcccl}
\hline Rootstock & $\mathrm{L}$ & $\mathrm{A}$ & $\mathrm{B}$ & $\mathrm{H}^{\circ}$ \\
\hline Okinawa & $56 \mathrm{a}^{*}$ & $16 \mathrm{~b}$ & $40 \mathrm{a}$ & $67 \mathrm{a}$ \\
Aldrighi & $52 \mathrm{a}$ & $23 \mathrm{a}$ & $35 \mathrm{a}$ & $56 \mathrm{ab}$ \\
Capdeboscq & $49 \mathrm{a}$ & $25 \mathrm{a}$ & $32 \mathrm{a}$ & $50 \mathrm{~b}$ \\
\hline C.V. (\%) & 14.7 & 36.0 & 26.3 & 25.3 \\
\hline
\end{tabular}

"Means followed by the same letter among rootstock are not different (Duncan, $p<0.05$ ). 
ness as a function of rootstocks is not clearly explained in the literature, probably due to indirect factors that affect rootstocks such as edafoclimatic conditions. Petri et al. (2007) mention about the decrease in flesh firmness during fruit ripeness period, and Fagundes and Yamanishi (2001) state that it could indicate the ripening stage or harvest time. However, the harvest in our study occurred in the same period, independently of the propagation method or rootstock (Figure 2).

Neither propagation method nor rootstock influenced on TSS. The value $9.4^{\circ}$ Brix found here is below of those cited by Rossi et al. (2004) for cv. Granada. These results agree with Giorge et al. (2005) but differ from data verified by Picolotto et al. (2009); Remorini et al. (2008) and Rocha et al. (2007). According to Argenta et al. (2004) TSS are affected mainly by orchard management and crop season. Consequently, the use of air layering propagation maintains the same quality standard as using seed propagation for the particular parameter analyzed.

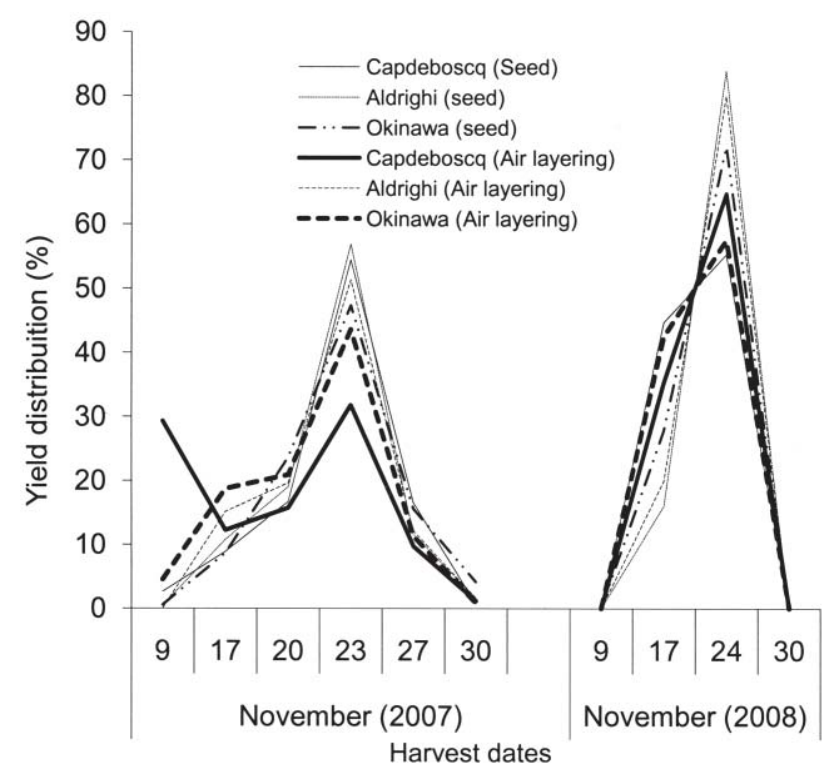

Figure 2 - Fruit ripening time according production distribution at each harvest date of the peach cv. Granada grafted on different rootstocks and using two propagation methods.
Titratable acidity was affected only by propagation method. The highest acidity value was verified when using air layering propagation, except for Okinawa where propagation did not differ between techniques. There were no differences among rootstocks (Table 2). The variation in acidity depends on year (Argenta et al., 2004). TSS/TA ratio reached 10.8 and was neither affected by propagation method nor rootstock. Even with differences on acidity, there was no difference in the fruit flavor, as verified in the TSS/TA ratio, regardless of propagation method.

The differences for total phenols depended on rootstocks and propagation methods. The highest amount of these compounds occurred when using both air layering propagation and the rootstock Okinawa, differing from Capdeboscq and Aldrighi. The use of seed propagation did not affect the rootstocks (Table 2). The higher amount of phenol compounds verified in fruits from air layering propagated rootstocks could be occurring due to the fasciculate root system, what also could be subject to superficial climatic variations. García et al. (2004) associate the compound formation to plant defense mechanism. According to Remorini et al. (2008) it is not possible to generalize the phenol synthesis in the epidermis because no clear tendency was observed, making the identification of a general behavior for the rootstocks difficult.

The investigations of the present study are not conclusive but it is already possible to verify that the air layering propagation using the scion cultivar Granada keeps similar or superior yield and the same fruit quality attributes whether compared to rootstocks propagated by the seed.

\section{Acknowledgements}

The authors thank to CNPq and UFPel/FAEM for the support.

\section{References}

Amarante, C.V.T.D.; Steffens, C.A.; Mota, C.S.; Santos, H.P.D. 2007. Radiation, photosynthesis, yield and fruit quality in apple 'Royal Gala' covered with hail screens. Pesquisa Agropecuária Brasileira 42: 925-931. (in Portuguese, with abstract in English).

Table 2 - Fruit flesh firmness, total titrable acidity and total phenol content of peach cv. Granada grafted on rootstocks propagated by air layering or seed.

\begin{tabular}{|c|c|c|c|c|c|c|}
\hline & \multicolumn{2}{|c|}{ Flesh firmness } & \multicolumn{2}{|c|}{ Total titrable acidity } & \multicolumn{2}{|c|}{ Total phenol } \\
\hline & Air layering & Seed & Air layering & Seed & Air layering & Seed \\
\hline & \multicolumn{2}{|c|}{ N } & \multicolumn{2}{|c|}{ \% of citric acid } & \multicolumn{2}{|c|}{ mg EAG $100 \mathrm{~g}^{-1}$} \\
\hline Aldrighi & $31.6 \mathrm{bB}^{*}$ & $34.3 \mathrm{aA}$ & $0.93 \mathrm{aA} *$ & $0.81 \mathrm{aB}$ & $74.52 \mathrm{bA}$ & $63.41 \mathrm{aB}$ \\
\hline Capdeboscq & 37.4 aA & 35.6 aA & $0.87 \mathrm{aA}$ & $0.79 \mathrm{aB}$ & $74.63 \mathrm{bA}$ & $61.67 \mathrm{aB}$ \\
\hline Okinawa & $33.8 \mathrm{bA}$ & $35.1 \mathrm{aA}$ & $0.87 \mathrm{aA}$ & $0.83 \mathrm{aA}$ & 83.85 aA & $62.55 \mathrm{aB}$ \\
\hline C.V. (\%) & 17.8 & & 4.6 & & 4.6 & \\
\hline
\end{tabular}

"Means followed with the same letter, lowercase on column for rootstock and uppercase on line for propagation method, are not different (Duncan, $p<0.05)$. 
Argenta, L.C.; Cantillano, F.F.; Becker, W.D. 2004. Postharvest technology for stone fruit trees. p. 333-367. In: Monteiro, L.B.; Mio, L.L.M.D.; Serrat, B.M.; Motta, A.C.; Cuquel, F.L., eds. Stone fruit trees: an ecological view. UFPR, Curitiba, PR, Brazil. (in Portuguese).

Baldini, E. 1992. General Arboriculture. Mundi-Prensa, Madrid, Spain. (in Italian).

Castro, L.A.S.D.E; Silveira, C.A.P. 2003. Vegetative propagation of peach trees by layering. Revista Brasileira Fruticultura 25: 368-370. (in Portuguese, with abstract in English).

Fachinello, J.C.; Hoffmann, A.; Nachtigal, J., eds. 2005. Propagation of Fruit Plants. Embrapa Informação Tecnológica, Brasília, DF, Brazil. (in Portuguese).

Fachinello, J.C.; Nachtigal, J.C.; Kersten, E. 1996. Fundamentals and practices in fruit production. Editora UFPEL, Pelotas, RS, Brazil. (in Portuguese).

Fagundes, G.R. Yamnishi, O. K. 2001. physical and chemical characteristics of fruits of papaya tree from 'solo' group commercialized in 4 establishments in Brasilia-DF. Revista Brasileira de Fruticultura 23: 541-545. (in Portuguese, with abstract in English).

García, E.; Rom, C.R.; Murphy, J.B. 2004. Comparison of phenolic content of 'liberty' apple (malus $x$ domestica) on various rootstocks Acta Horticulturae 658: 57-60

Giorgi, M.; Capocasa, F.; Scalzo, J.; Murri, G.; Battino, M.; Mezzetti, B. 2005. The rootstock effects on plant adaptability, production, fruit quality, and nutrition in the peach (cv. 'Suncrest'). Scientia Horticulturae 107: 36-42.

López-Bucio, J. Cruz-Ramirez, A. Herrera-Etrella. 2003.The role of nutrient availability in regulating root architecture. Current Opinion in Plant Biology 6:280-287.

Loreti, F.; Massai, R. 2002. The peach rootstock. L' Informatore Agrario 51: 36-42. (in Italian, with abstract in English).

Lynch, J. 1995. Root architecture and plant productivity. Plant Physiology 109: 7-13.

Nava, G.A.; Dalmago, G.A.; Bergamaschi, H.; Marodin, G.A.B. 2009. Phenology and yield of peach 'Granada' with hydrogenated cyanamide and boron. Revista Brasileira de Fruticultura 31: 297-304. (in Portuguese, with abstract in English).

Pereira, F.M.; Mayer, N.A. 2005. Peach: Technologies for the Production of Seedlings. Funep, Jaboticabal, SP, Brazil. (in Portuguese).

Petri, J.L.; Leite, G.B.; Argenta, L.C. 2007. Efficacy of avg treatment in the fall and fruit ripening apple cultivar Imperial Gala. Revista. Brasileira de Fruticultura 29: 239-244. (in Portuguese, with abstract in English).
Picolotto, L.; Berto, R.M.; Pazin, D.; Pasa, M.D.S.; Schmitz, J.D.; Prezotto, M.E.; Betemps, D.; Bianchi, V.J.; Fachinello, J.C. 2009. Vegetative, phenological and productive characteristics of the 'Chimarrita' peach grafted on different rootstocks. Pesquisa Agropecuária Brasileira 44: 583-589. (in Portuguese, with abstract in English).

Remorini, D.; Tavarini, S.; Degl'innocenti, E.; Loreti, F.; Massai, R.; Guidi, L. 2008. Effect of rootstocks and harvesting time on the nutritional quality of peel and flesh of peach fruits. Food Chemistry 110: 361-367.

Rocha, M.D.S.; Bianchi, V.J.; Fachinello, J.C.; Schmitz, J.D.; Pasa, M.D.S.; Silva, J.B.D. 2007. Agronomic initial performance of the cv. Chimarrita grafted on five peach rootstocks. Revista Brasileira de Fruticultura 29: 583-588. (in Portuguese, with abstract in English).

Rossi, A; Fachinello, J.C.; Rufato, L.; Parisoto, E.; Picolotto, L. Kruger, L.R. 2004. Behavior 'Granada' peach on different rootstocks. Revista Brasileira de Fruticultura 26: 446-449. (in Portuguese, with abstract in English).

Singleton, V.L.; Rossi Junior, J.A. 1965. Colorimetry of total phenolics with phosphomolybdic-phosphotungstic acid reagents. American Journal of Enology and Viticulture 16: 144158.

Sorgona, A.; Abenavoli, M.R.; Gringeri, P.G.; Lupini, A.; Cacco, G. 2007. Root architecture plasticity of citrus rootstocks in response to nitrate availability. Journal of Plant Nutrition 30: 1921-1932.

Webster, A.D. 2004. Vigour mechanisms in dwarfing bootstocks for temperate fruit trees. Acta Horticulturae 658: 29-41.

Zarrouk, O.; Gogorcena, Y.; Gómez-Aparisi, J.; Betrán, J.A.; Moreno, M.A. 2005. Influence of almond $\times$ peach hybrids rootstocks on flower and leaf mineral concentration, yield and vigour of two peach cultivars. Scientia Horticulturae 106: 502514.

Zonta, E.P.; Machado, A.A., eds. 1995. SANEST - Statistical Analysis System for Microcomputers. UPPel, Pelotas, RS, Brazil. (in Portuguese).

Received April 13, 2009

Accepted May 19, 2010 